\title{
Preparation and Characterization of Porous Titania Ceramic Scaffolds
}

\author{
Inga Narkevica ${ }^{1}$, Laura Stradina ${ }^{2}$, Vladimir Yakushin ${ }^{3}$, Jurijs Ozolins ${ }^{4}$, \\ ${ }^{1,2,}{ }^{4}$ Riga Technical University, ${ }^{3}$ Latvian State Institute of Wood Chemistry
}

\begin{abstract}
Biocompatible ceramics have recently attracted increasing attention as porous scaffolds that stimulate and guide natural bone regeneration. Due to excellent biocompatibility of titania (titanium dioxide or $\mathrm{TiO}_{2}$ ) porous three-dimensional (3D) $\mathrm{TiO}_{2}$ structures have been proposed as promising scaffolding materials for inducing bone formation from the surrounding environment and for enhancement of vascularisation after implantation. In this paper, 3D porous $\mathrm{TiO}_{2}$ ceramic scaffolds were produced via polymer foam replica method. This work deals with several important issues that are considered to be important for 3D scaffolds applied to regenerate bone tissue: pore size, porosity and mechanical strength. $\mathrm{TiO}_{2}$ ceramic scaffolds with pore size $300 \mu \mathrm{m}-700 \mu \mathrm{m}$ and porosity $>90 \%$ were obtained. Scaffolds showed fully open and interconnected pore structure that remained after recoating them with low viscosity $\mathrm{TiO}_{2}$ slurry. By optimising thermal treatment conditions grain growth and collapse of struts could be controlled in a way that resulted in higher compressive strength. Recoating greatly improved compressive strength and it reached $0.74 \pm 0.08 \mathrm{MPa}$ after two coatings without causing changes in the open pore structure.
\end{abstract}

Keywords - Titanium dioxide, scaffold, microstructure, porosity, strength.

\section{INTRODUCTION}

The use of scaffolds as sacrificial templates for bone ingrowth is the basis of bone tissue regeneration. The main reasons for using bone scaffolds are: to provide an environment for bone formation, to maintain the space and at the same time to supply mechanical support to the skeleton during the healing process [1]. Thus an ideal scaffold should be three-dimensional and highly porous with an interconnected pore network for cell growth and for flow transport of nutrients and metabolic waste. The mechanical properties of the scaffold should match those of tissue at the site of the implantation [2], [3].

One of the materials that can be used to produce 3D scaffolds is titania $\left(\mathrm{TiO}_{2}\right)$ ceramics. $\mathrm{TiO}_{2}$ have attracted particular attention for the use as a bone tissue regeneration material due to its excellent mechanical properties compared to other ceramic materials, biocompatibility and good osteoconductivity [2]-[6]. Fabrication of highly porous $\mathrm{TiO}_{2}$ ceramic scaffolds with interconnected pore structure has been previously reported [7]-[10]. The most widely used technique for fabrication of such structures is polymer foam replica method [8]-[13]. It was invented by Schwartzwalder and Somers in 1963 [14]. The polymer that has the desired macrostructure simply serves as a sacrificial template for the ceramic coating [10]-[14]. Using polymer foam replica method a porous ceramic with porosity from $40 \%$ to $95 \%$ and with pore sizes between $200 \mu \mathrm{m}$ and $2 \mathrm{~mm}$ can be obtained. Thus this technique is the most popular method to produce macroporous ceramics. It is also simply adjustable, flexible and relatively inexpensive [13].

The aim of the presented research was to adjust this technique to produce porous $3 \mathrm{D} \mathrm{TiO}_{2}$ ceramic scaffolds with interconnected pore structure. This work deals with several important issues that are considered to be important for 3D scaffolds applied to regenerate bone tissue, including pore size, porosity and mechanical strength.

\section{MATERIALS AND METHODS}

\section{A. Sample Preparation}

$\mathrm{TiO}_{2}$ ceramic scaffolds were prepared using polymer foam replica method. Commercially available titanium dioxide with average particle size $180 \mathrm{~nm}$ (Sachtleben Chemie $\mathrm{GmbH}$, HOMBITAN LW - S), $5 \%$ polyvinyl alcohol solution (Polysciences, Inc.) and deionised water were used as raw materials to prepare ceramic slurry (Table I). The slurry was homogenised by ball milling for $1 \mathrm{~h}$ at $300 \mathrm{rpm}$.

TABLE I

SLURRY COMPOSITION

\begin{tabular}{|l|l|}
\hline Raw material & Mass fraction, $\%$ \\
\hline Titania & 70 \\
\hline Water & 21 \\
\hline $5 \%$ polyvinyl alcohol solution & 9 \\
\hline
\end{tabular}

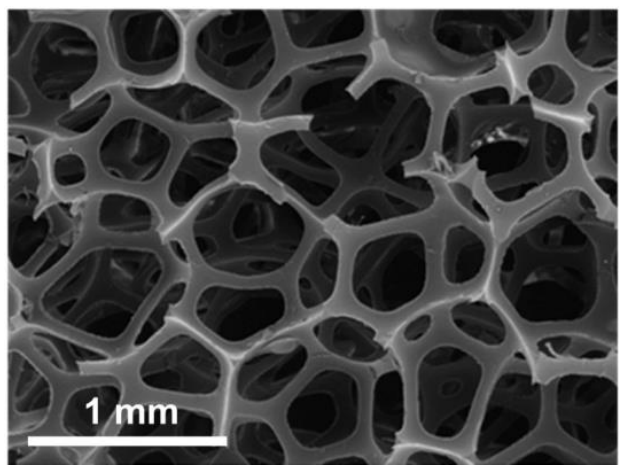

Fig. 1. SEM micrograph of PU foam template.

The polyurethane (PU) foam templates (Vitabaltic International) with fully interconnected pore structure (Fig. 1) were cut to size by punching with a metal stamp. Obtained 
cylinders with $10 \mathrm{~mm}$ diameter were washed in ethanol using a Soxhlet extractor and dried in air. Cylindrical PU foam templates then were dipped into the ceramic slurry. Excess slurry was squeezed out of the templates to ensure that only a thin layer of slurry uniformly covered PU foam surface without blocking the pores. After drying for $24 \mathrm{~h}$, the polymer was slowly burned out by heating to $450{ }^{\circ} \mathrm{C}$ at a heating rate of $0.5^{\circ} \mathrm{C} / \mathrm{min}$. After $1 \mathrm{~h}$ holding time at $450{ }^{\circ} \mathrm{C}$, the temperature was raised to $1100{ }^{\circ} \mathrm{C}$ at a rate of $3{ }^{\circ} \mathrm{C} / \mathrm{min}$ and held at $1100{ }^{\circ} \mathrm{C}$ for $10 \mathrm{~h}$.

The scaffolds were sintered at different temperatures $\left(1300{ }^{\circ} \mathrm{C}-1500{ }^{\circ} \mathrm{C}\right) \quad$ with different holding times $(10 \mathrm{~h}-30 \mathrm{~h})$. Some of the scaffolds that were sintered at $1400{ }^{\circ} \mathrm{C}$ temperature for $20 \mathrm{~h}$ were additionally coated with low viscosity slurry $\left(\mathrm{TiO}_{2}\right.$ mass fraction $\left.20 \%\right)$ using a vacuum infiltration method. After slurry infiltration scaffolds were centrifuged at $1000 \mathrm{rmp}$ for $1 \mathrm{~min}$ to remove excess slurry that could have blocked the pores, dried in air and sintered at the same conditions as previously $-1400{ }^{\circ} \mathrm{C}$ for $20 \mathrm{~h}$.

\section{B. Characterization of Materials}

Identification of crystalline phases of sintered ceramics was carried out using X-ray diffraction (XRD). X-ray diffraction patterns were obtained using an X-ray diffractometer PANalytical $\mathrm{X}^{`}$ Pert PRO. $\mathrm{Cu} \mathrm{K} \alpha$ filtered radiation in $2 \theta$ range from $20^{\circ}$ to $65^{\circ}$ was used.

The microstructure of scaffolds was investigated using scanning electron microscope (SEM) Tescan Mira/LMU and digital microscope KEYENCE VHX 2000. Before SEM investigations samples were sputter coated with a gold layer. The samples were observed at $15 \mathrm{kV}$ accelerating voltage.

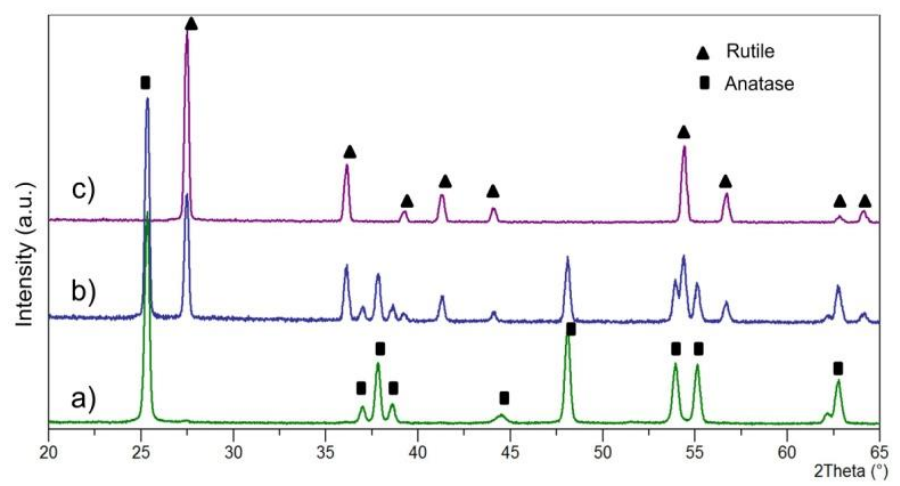

Fig. 2. XRD patterns of anatase powder (a) and of the obtained scaffolds after sintering at $1000{ }^{\circ} \mathrm{C}\left(\right.$ b) or $1300{ }^{\circ} \mathrm{C}(\mathrm{c})$.
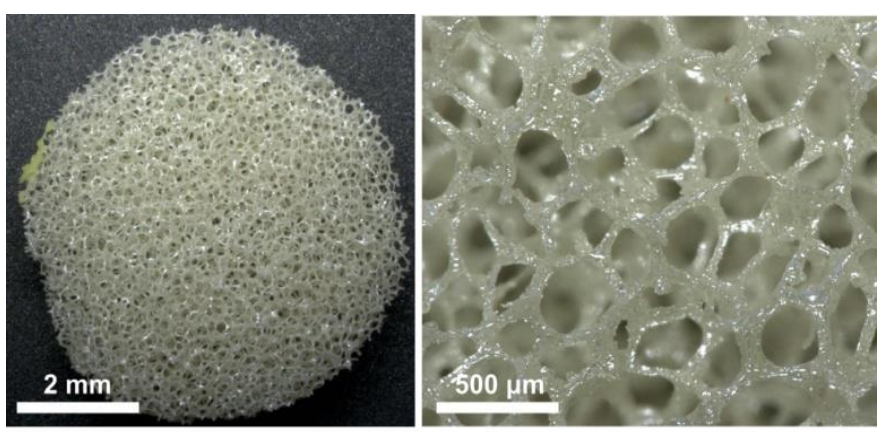

Fig. 3. Digital microscopy images of the obtained scaffolds.
Total porosity $(\Pi)$ of the scaffolds was measured using gravimetry, according to the equation:

$$
\Pi=1-\rho_{\text {scaffold }} / \rho_{\text {titania }}
$$

Here $\rho_{\text {titania }}$ is the density of $\mathrm{TiO}_{2}$ (rutile) and $\rho_{\text {scaffold }}$ is the apparent density of the scaffold measured by dividing the weight of the scaffold by the volume of the scaffold. Sample shrinkage after sintering was calculated by geometric method, taking into account the changes of scaffold dimensions.

The mechanical strength of scaffolds was determined using a compression test (A Static Materials Testing Machine Z010 TN (Zwick GmbH \& Co. KG). Scaffolds were preloaded with $0.1 \mathrm{~N}$. The speed of compression tests was $10 \%$ per $1 \mathrm{~min}$.

\section{RESULTS AND DISCUSSION}

\section{A. Effect of Heat Treatment on the Composition of Scaffolds}

In order to examine the phase composition of $\mathrm{TiO}_{2}$ scaffolds XRD was performed on $\mathrm{TiO}_{2}$ (anatase) powder and on scaffolds after sintering at $1000^{\circ} \mathrm{C}$ or $1300{ }^{\circ} \mathrm{C}$ temperature (Fig. 2). XRD pattern of samples sintered at $1000{ }^{\circ} \mathrm{C}$ showed the characteristic peaks of both $\mathrm{TiO}_{2}$ crystalline modifications (anatase and rutile). Thus this confirmed phase transformation during scaffold sintering. In the transformation process bonds break in the anatase structure. This allows the rearrangement of the $\mathrm{Ti}^{-} \mathrm{O}_{6}$ octahedra and leads to a more compact structure formation and formation of rutile phase [15]. Increasing sintering temperature up to $1300{ }^{\circ} \mathrm{C}$ a complete phase transition from anatase to rutile crystalline modification took place and stable rutile modification was obtained.

\section{B. Porosity and Mechanical Properties}

Porous $\mathrm{TiO}_{2}$ ceramic scaffolds with fully open and interconnected pore structure have been obtained (Fig. 3 and Fig. 4). The porosity of the scaffolds was in the range from $92 \%$ to $94 \%$ and pore size was from $300 \mu \mathrm{m}$ to $700 \mu \mathrm{m}$, independently of the sintering temperature (from $1300{ }^{\circ} \mathrm{C}$ to $1500{ }^{\circ} \mathrm{C}$ ) and independently of the holding time at the evaluated temperatures $(10 \mathrm{~h}$ to $30 \mathrm{~h})$. Obtained pore size and porosity is appropriate to ensure cell migration throughout the scaffold structure and ensure vascularisation, if scaffolds are used for bone tissue regeneration.

If the temperature of thermal treatment is increased from $1100{ }^{\circ} \mathrm{C}$ to $1500{ }^{\circ} \mathrm{C}$, grain growth occured. At $1100{ }^{\circ} \mathrm{C}$ finegrained ceramics can be obtained, but at higher temperatures inhomogeneous grains with grain size up to $50 \mu \mathrm{m}$ were observed (Fig. 4). As can be seen in Fig. 4, during PU foam pyrolysis process hollow struts (shown using a rectangle) and voids (shown using an arrow) in the ceramic wall structure were produced; these had a direct effect on mechanical strength of the ceramic material.

By optimising thermal treatment conditions grain growth and collapse of struts could be controlled in a way that resulted in higher compressive strength. Increasing the heat treatment temperature of the ceramic scaffolds from $1100{ }^{\circ} \mathrm{C}$ to $1500{ }^{\circ} \mathrm{C}$ resulted in grains compacting and the disappearance of microcracks was promoted, thus slightly 
decreasing the defect quantity in the ceramic wall structure (Fig. 4).

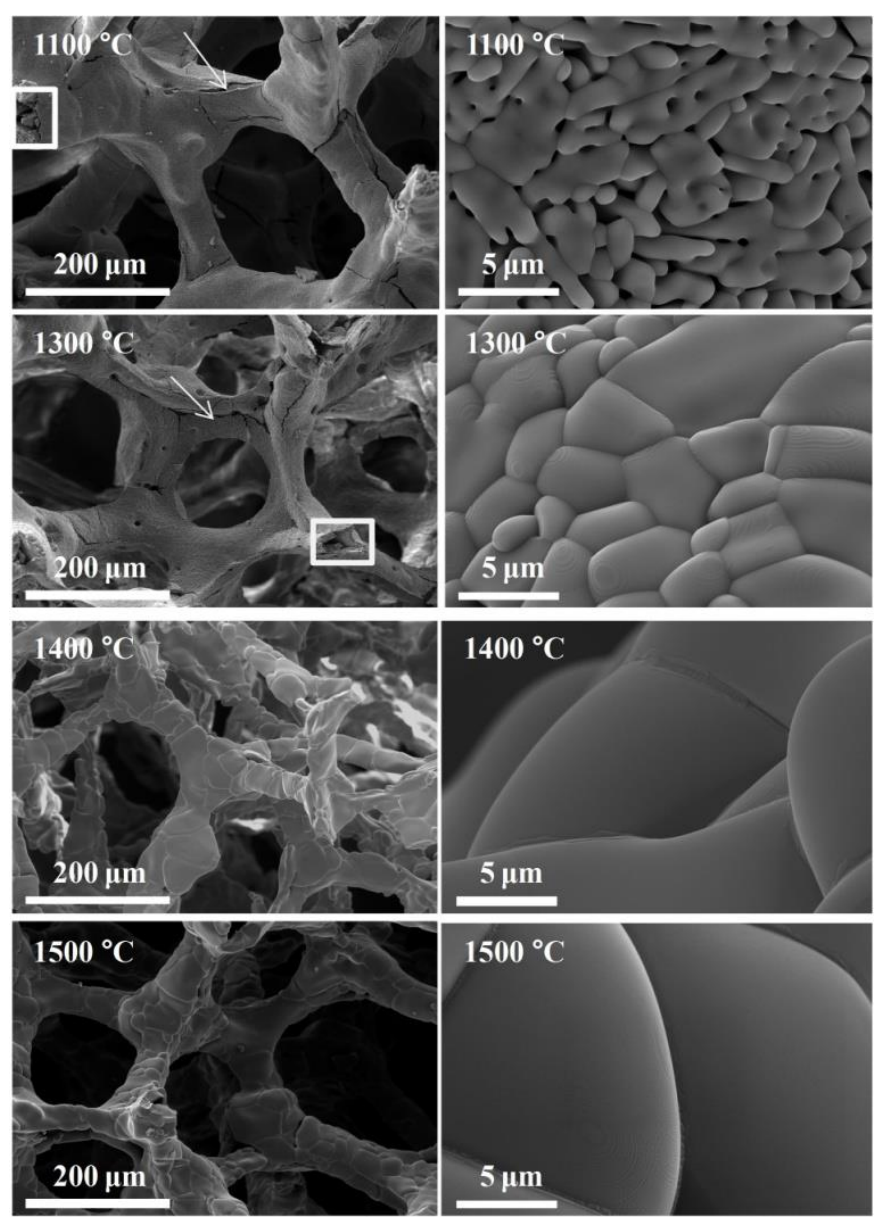

Fig. 4. The effect of thermal treatment temperature on the microstructure of the sintered scaffolds.

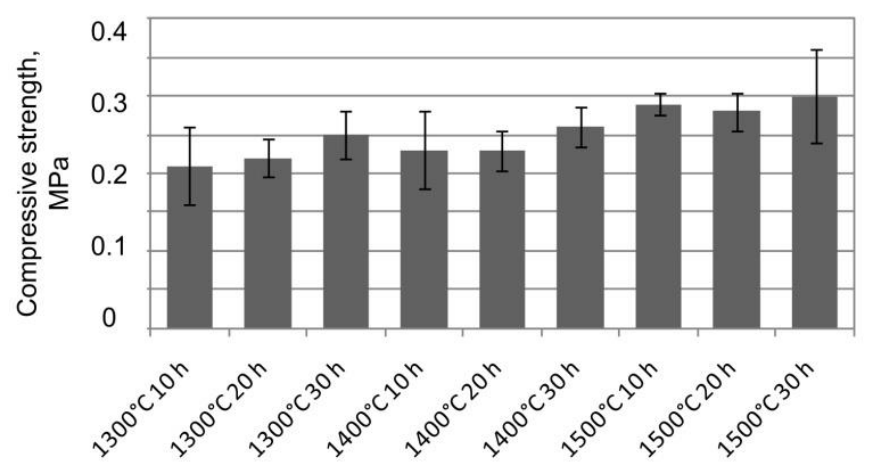

Fig. 5. Compressive strength of the sintered scaffolds.

During the heat treatment reduction of scaffold dimensions also was observed and the thermal shrinkage of the scaffold volume reached $35 \%$ at $1100{ }^{\circ} \mathrm{C}$ and up to $60 \%$ at the temperature range $1300{ }^{\circ} \mathrm{C}-1500{ }^{\circ} \mathrm{C}$.

The effect of sintering temperature and holding time at evaluated temperatures on mechanical strength of scaffolds is shown in Fig. 5. It was experimentally determined that increasing heat treatment temperature and holding time at evaluated temperature slightly increased mechanical strength of the sintered ceramic scaffolds and the highest mechanical strength $(0.3 \pm 0.06 \mathrm{MPa})$ was obtained for scaffolds after heat treatment at $1500^{\circ} \mathrm{C}$ for $30 \mathrm{~h}$.
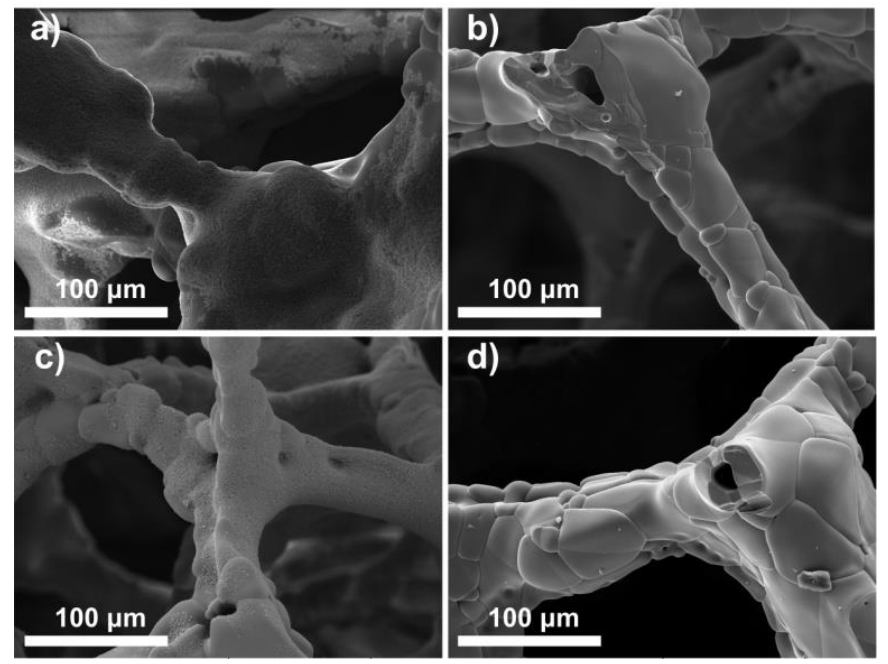

Fig. 6. SEM micrographs of $\mathrm{TiO}_{2}$ scaffolds before (a) and after $1^{\text {st }}$ coating and sintering (b); before (c) and after $2^{\text {nd }}$ coating and sintering (d)

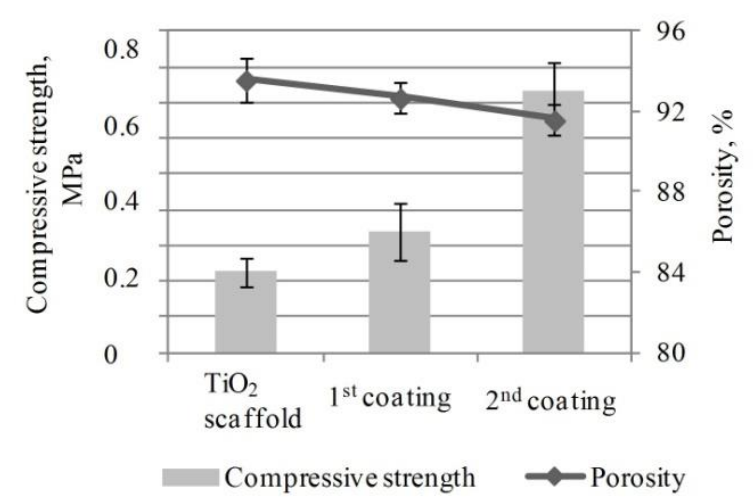

Fig. 7. Compressive strength and porosity of the recoated scaffolds.

\section{Effect of Recoating Process on Scaffold Properties}

Scaffolds sintered at $1400{ }^{\circ} \mathrm{C}$ temperature for $20 \mathrm{~h}$ were recoated with low viscosity $\mathrm{TiO}_{2}$ slurry by vacuum infiltration method and were further sintered at the same thermal treatment conditions as before. Results showed that recoating procedure slightly decreased porosity by partially filling the micropores. Voids and folds remained in the scaffold wall structure and wall surface as illustrated in Fig. 6. As shown in Fig. 7, recoating scaffolds with low viscosity slurries improved the compressive strength and it reached $0.74 \pm 0.08 \mathrm{MPa}$ after three coatings without causing significant changes in porosity and open pore structure.

\section{CONCLUSION}

$\mathrm{TiO}_{2}$ ceramic scaffolds with pore size $300 \mu \mathrm{m}-700 \mu \mathrm{m}$ and $>90 \%$ porosity were produced via polymer foam replica method. Scaffolds showed fully open and interconnected pore structure that remained after recoating them with low viscosity $\mathrm{TiO}_{2}$ slurry. By optimising thermal treatment conditions, the grain growth and collapse of struts could be controlled in a 
way that resulted in higher compressive strength. Optimal sintering temperature were $1500{ }^{\circ} \mathrm{C}$ and optimal holding time was $30 \mathrm{~h}$. Recoating greatly improved compressive strength and it reached $0.74 \pm 0.08 \mathrm{MPa}$ after 2 coatings without causing changes in the open pore structure.

\section{ACKNOWLEDGEMENT}

This work was supported by the Latvian State Research Program "Development of innovative multifunctional materials, signal processing and information technology for competitive science intensive products" project No. 4 "New materials and technologies for evaluating biological tissue, and replace".

\section{REFERENCES}

1. Chan, B.P., Leong, K.W. Scaffolding in tissue engineering: general approaches and tissue-specific considerations. European Spine Journal, 2008, vol. 17, pp. 467-479. http://dx.doi.org/10.1007/s00586-008-0745-3

2. Tiainen, H., Wohlfahrt, J.C., Verket, A., Lyngstadaas, S.P., Haugen, H.J. Bone formation in $\mathrm{TiO}_{2}$ bone scaffolds in extraction sockets of minipigs. Acta Biomateriala, 2014, vol. 8, pp. 2384-2389. http://dx.doi.org/10.1016/j.actbio.2012.02.020

3. Sabetrasekh, R., Tiainen, H., Lyngstadaas, S.P., Reseland, J., Haugen, H.J. A novel ultra-porous titanium dioxide ceramic with excellent biocompatibility. Journal of Biomaterial Applications, 2011, vol. 25, pp. 559-580. http://dx.doi.org/10.1177/0885328209354925

4. Verket, A., Tiainen, H., Haugen, H.J., Lyngstadaas, S.P., Nilsen, O., Reseland, J.E. Enhanced osteoblast differentiation of scaffolds coated with $\mathrm{TiO}_{2}$ compared to $\mathrm{SiO}_{2}$ and $\mathrm{CaP}$ coating. Biointerphases, 2012, vol.7, N 36 . http://dx.doi.org/10.1007/s13758-012-0036-8

5. Wei, J., Chen, Q.Z., Stevens, M.M., Roether, J.A., Boccaccini A.R. Biocompatiblity and bioactivity of PDLAA/TiO ${ }_{2}$ ans PDLLA/TiO $/$ Bioglass nanocomposites. Materials Science and Engineering $C$, 2008, vol. 28, pp. 1-10. http://dx.doi.org/10.1016/j.msec.2007.01.004

6. Haugen, H.J., Monjo, M., Rubert, M., Verket, A., Lyngstadaas, S.P., Ellingsen, J.E., Ronold, H.J, Wohlfahrt, J.C. Porous ceramic titanium dioxide scaffolds promote bone formation in rabbit peri-implant cortical defect model. Acta Biomateriala, 2013, vol. 9, pp. 5390-5399. http://dx.doi.org/10.1016/i.actbio.2012.09.009

7. Narkevica, I., Ozolins, J., Berzina-Cimdina, L. Effects of surface modification of titania on in vitro apatite-forming ability. Key Enginering Materials, $2014, \quad$ vol. $\quad 604, \quad$ pp. $196-199$. http://dx.doi.org/10.4028/www.scientific.net/KEM.604.196

8. Haugen, H.J., Will, J., Kohler, A., Hopfner U, Aigner, J., Wintermantel, E. Ceramic $\mathrm{TiO}_{2}$-foams: characterization of potential scaffold. Journal of the European Ceramic Society, 2004, vol. 24, pp. 661-668. http://dx.doi.org/10.1016/S0955-2219(03)00255-3

9. Novak, S., Druce, J., Chen, Q.Z., Boccaccini, A.R. $\mathrm{TiO}_{2}$ foams with poly(D,L-lactic acid) (PDLLA) and PDLAA/Bioglass coating for bone tissue engineering scaffolds. Journal of Material Science, 2009, vol. 44, pp. 14421448. http://dx.doi.org/10.1007/s10853-008-2858-9

10. Tiainen, H., Eder, G., Nilsen, O., Haugen, H.J. Effect of $\mathrm{ZrO}_{2}$ addition on the mechanical properties of porous $\mathrm{TiO}_{2}$ bone scaffolds. Materials

Inga Narkevica, Laura Stradiņa, Vladimirs Jakušins, Jurijs Ozoliṇ̌s. Porainu titāna dioksīda keramikas pamatņu ieguve un raksturojums.

Pasaulē arvien vairāk pētījumu tiek veltīti jaunu, sintētisku biomateriālu izstrādei, kas paredzēti bojātu cieto audu aizvietošanai. Liela interese kaulaudu inženierijas pētījumos ir veltīta trīsdimennsionālām audu pamatnēm ar pilnībā caurejošu poru struktūru, jo tā var veicināt vaskularizāciju, dzīvo šūnu piesaisti un proliferāciju. Viens no biosaderīgiem materiāliem, kuru var izmantot bojātu kaulaudu aizvietošanai, ir poraina $\mathrm{TiO}_{2}$ keramika. $\mathrm{TiO}_{2}$ keramikai ir labākas mehāniskās īpašības nekā citiem porainiem keramiskiem materiāliem, un tai piemīt osteokonduktīvas īpašības. Salīdzinoši vienkārša metode porainu struktūru iegūšanai ir sintētiska prekursora piesūcināšana. Darbā kā prekursors poraino pamatnu iegūšanai izmantotas elastīgas poliuretāna putas. Tās tika piesūcinātas ar $\mathrm{TiO}_{2}$ šlikeri, kas sastāv no TiO ${ }_{2}$ (anatāza) pulvera, polivinilspirta šķ̄iduma un $\mathrm{H}_{2} \mathrm{O}$. Šlikera homogenizāciju veica planetārajās bumbu dzirnavās. Paraugu termisko apstrādi veica divās stadijās: organisko savienojumu izdedzināšana (1) un porainas keramikas saķepināšana $1300{ }^{\circ} \mathrm{C}-1500{ }^{\circ} \mathrm{C}, 10 \mathrm{~h}-30 \mathrm{~h}(2)$. Daļu paraugu atkārtoti pārklāja ar zemas viskozitātes $\mathrm{TiO}_{2}$ šlikeri un termiski apstrādāja gaisā $1400{ }^{\circ} \mathrm{C}$ temperatūrā 20 h. Parādīts, ka, izmantojot prekursora piesūcināšanas metodi, iespējams iegūt porainas pamatnes ar piln̄̄bā atvērtu, caurejošu poru struktūru, ar poru izmēriem $300 \mu \mathrm{m}-700 \mu \mathrm{m}$ un
Science and Engineering C, 2012, vol. 32, pp. 1386-1393.
http://dx.doi.org/10.1016/j.msec.2012.04.014 htp.//x.doi.org/10.1016/j.msec.2012.04.014

titanium, H., Lyngstadaas, S.P., Ellingsen, J.E., Haugen, H. Ultra-porous Materials Sciene: Materials in Medicine, 2010, vol. 21, pp. 2783-2792. http://dx.doi.org/10.1007/s10856-010-4142-1

2. Tiainen, H., Wiedmer, D., Haugen, H.J. Processing of highly porous $\mathrm{TiO}_{2}$ European Ceramic Society, 2013, vol 33, Journal of the http://dx.doi.org/10.1016/j.jeurceramsoc.2012.08.016

13. Studart, A.R., Gonzenbach, U.T., Tervoort, E., Gauckler, L.J. Procession routes to macroporous ceramics: a review. Journal of American $\begin{array}{lll}\text { Society, } 2006, \quad \text { vol. } & 89, \quad \mathrm{~N} \quad 6, \\ \text { http://dx.doi.org/10.1111/j.1551-2916.2006.01044.x }\end{array}$

14. Schwartzwalder, K., Somers, A.V. Method of making a porous shape of sintered refractory ceramic articles. US patent No. 3090094, 163.

5.Hanaor D.A.H., Sorrell C.C. Review of the anatase to rutile phase transformation. Journal of Material Science, 2011, vol. 46, pp. 855-874. http://dx.doi.org/10.1007/s10853-010-5113-0

Narkevica, Mg. sc. ing., is a doctoral student at Riga Technical "University, Faculty of Materials Science and Applied Chemistry, programme Engineering, RTU Rudolfs Cimdins Riga Biomaterials Innovation and Development Centre. She is an author of 4 publications in the scientific fields tioxide ceramics, its properties and its use as a biomaterial. Her ceramic scaffolds for bone tissue engineering.

E-mail: inga.narkevica@rtu.lv Tecnical University, Faculty of Materials Science and Applied Chemistry, programme "Nanotechnology for Materials". Her main fields of interest are
materials for bone defect regeneration, porous materials and titanium dioxide ceramics.

Vladimir Yakushin graduated from Riga Polytechnic Institute in 1971. He received $D r$. sc. ing. degree in polymer and reinforced plastics technology in

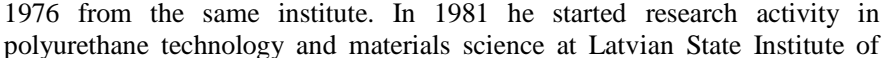
Wood Chemistry, Laboratory for Polymers. He now is a leading researcher, responsible for the development and testing of rigid polyurethane foams and coatings. His research activities include properties of epoxy composites reinforced with various fillers, crosslinked polyurethane coatings and behavior

E-mail: yakushin@edi.lv

Jurijs Ozolins, Dr. sc. ing., professor, is a leading researcher at Riga Technical University, Faculty of Materials Science and Applied Chemistry, more than 100 publications in the fields of polymers technology, environmental engineering (mass transfer processes, properties of titanium dioxide ceramics and their use, microbiological contamination of drinking water) and application of bioceramics. He is the lecturer for the following Engineering, Heat Transfer Processes and Equipment, Special Processes and Equipment, Processes in Materials Technology.

E-mail: jurijs.ozolins@rtu.lv cryogenic temperatures.
crold 
porainību virs 90 \%. Palielinot poraino pamatnu termiskās apstrādes temperatūru no $1300{ }^{\circ} \mathrm{C}$ līdz $1500{ }^{\circ} \mathrm{C}$, TiO $\mathrm{O}_{2}$ keramikas graudi labāk sablīvējas, kas veicina mikroplaisu samazināšanos. Eksperimentāli noteikts, ka, palielinot termiskās apstrādes temperatūru un izturēšanas laiku, uzlabojas poraino pamatnu mehāniskā izturība. Pamatnēm, kas apdedzinātas $1500^{\circ} \mathrm{C}$ temperatūrā $30 \mathrm{~h}$, izturība spiedē sasniedz $0,3 \pm 0,06 \mathrm{MPa}$. Atkārtoti pārklājot porainās pamatnes ar zemas viskozitātes $\mathrm{TiO}_{2}$ šlikeri, pēc termiskās apstrādes saglabājas atvērto poru struktūra un būtiski

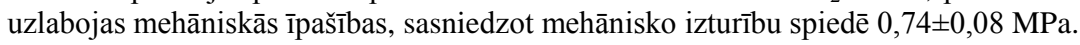

Инга Наркевица, Лаура Страдиня, Владимир Якушин, Юрий Озолиньш. Получение и характеристика пористых керамических подложек на основе диоксида титана.

Во многих странах всё больше проводимых исследований связано с разработкой и созданием новых синтетических биоматериалов для замещения твердых поврежденных тканей. В инженерных разработках костной ткани особый интерес уделяется тканевым подложкам 3D со сквозной пористой структурой, способствующей васкуляризацию ткани, присоединению живых клеток и их пролиферации. Одним из биосовмещенных материалов, применяемых для замещения поврежденных костных тканей, является пористая керамика на основе диоксида титана, обладающая лучшими механическими свойствами и остеокондуктивностью. Относительно простым методом получения таких материалов является пропитка синтетических прекурсоров. В работе в качестве прекурсора для получения пористой подложки использовали эластичную полиуретанную пену, пропитанную шликером $\mathrm{TiO}_{2}$, состоящим и порошка $\mathrm{TiO}_{2}$ в форме анатаза, - раствора поливинилового спирта и воды. Гомогенизация шликера проводилась в планетарной шаровой мельнице, термическую обработку осуществляли в двух стадиях: выжигание органических соединений и спекание пористой керамики при высоких температурах $\left(1300-1500{ }^{\circ} \mathrm{C}\right)$ с разным временем выдержки $(10-30 \mathrm{~h})$. Часть образцов покрывались шликером $\mathrm{TiO}_{2}$ низкой вязкости, используя метод вакуумной инфильтрации с последующей термической обработкой в воздухе в течение $20 \mathrm{~h}$. Полученные результаты свидетельствуют о том, что пористые подложки с полностью открытой проходящей структурой пор размером от 300 мкм до 700 мкм и пористостью выше $90 \%$ получают при использовании метода пропитки прекурсора. С увеличением температуры термической обработки пористых подложек от $1300{ }^{\circ} \mathrm{C}$ до $1500{ }^{\circ} \mathrm{C}$ зерна ТіО ${ }_{2}$ керамики уплотняются более эффективно. Это способствует значительному уменьшению количества микротрещин. Экспериментально установлено, что повышение температуры и время термической обработки улучшает механическаю прочность пористых керамических подложек. При температуре обжига пористых подложек $1500{ }^{\circ} \mathrm{C}$ в течение $30 \mathrm{~h}$ механическая прочность образцов достигает $0,3 \pm 0,06 \mathrm{MPa}$. При повторном покрытии образцов пористых подложек шликером $\mathrm{TiO}_{2}$ низкой вязкости после термической обработки сохраняется открытая структура пор и существенно улучшаются механические свойства подложек, значения

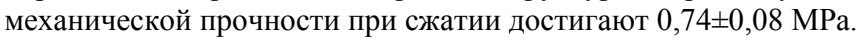

